\title{
Article
}

http://dx.doi.org/10.11646/phytotaxa.208.3.4

\section{Putterlickia neglecta (Celastraceae), a new species from southern Africa}

\author{
MARIE JORDAAN ${ }^{1,3}$, RICHARD G.C. BOON² \& ABRAHAM E. VAN WYK ${ }^{1 *}$ \\ ${ }^{1}$ H.G.W.J. Schweickerdt Herbarium, Department of Plant Science, University of Pretoria, Pretoria, 0002 South Africa. \\ ${ }^{2}$ Environmental Planning and Climate Protection Department, eThekwini Municipality, Durban, 4000 South Africa. \\ ${ }^{3}$ Previous address: South African National Biodiversity Institute, Private Bag X101, Pretoria, 0001 South Africa. \\ *Author for correspondence. E-mail: braam.vanwyk@up.ac.za
}

\begin{abstract}
Putterlickia neglecta, a new species here described and illustrated, is known from South Africa (Mpumalanga and northeastern KwaZulu-Natal), Swaziland and southern Mozambique. It is considered a near-endemic to the Maputaland Centre of Endemism. Plants grow as a shrub or small tree in savanna and thicket, or in the understory of inland, coastal and dune forests. Vegetatively it superficially resembles $P$. verrucosa, the species with which it has hitherto most often been confused. Both species have stems with prominently raised lenticels, but $P$. neglecta differs from $P$. verrucosa in having sessile to subsessile leaves with mostly entire, revolute leaf margins, flowers borne on pedicels $8-15 \mathrm{~mm}$ long, with petals up to $6 \mathrm{~mm}$ long and spreading or slightly recurved. Putterlickia verrucosa has leaves with distinct petioles, spinulose-denticulate margins, much smaller flowers borne on pedicels up to $4 \mathrm{~mm}$ long, with petals up to $2 \mathrm{~mm}$ long and erect or slightly spreading. The relatively large flowers of $P$. neglecta resemble those of $P$. pyracantha, but the latter differs in having stems with obscure or sunken lenticels, leaf margins entire or spinulose-denticulate and inflorescence axes as well as pedicels usually reddish. A comparative table to distinguish among the five currently recognized species of Putterlickia is provided.
\end{abstract}

Key words: Celastroideae, classification, evolution, Gymnosporia, Maputaland Centre of Endemism, lenticels, morphology, nomenclature, paraphyly, phylogeny, taxonomy

\section{Introduction}

The genus Putterlickia Endlicher (1840: 1086), a distinctive monophyletic group (Simmons et al. 2008; McKenna et al. 2011) confined to southern Africa, has in recent years been treated as comprising four species (Jordaan \& Van Wyk 1998: 322; Archer \& Jordaan 2003: 360). It is distinguished from Gymnosporia (Wight \& Arnott 1834: 159) Hooker (1862: 359, 365), its closest ally, by having bisexual flowers, (4-)6-10 ovules per locule, capsules longer than $10 \mathrm{~mm}$, and the stems of most species covered by distinct lenticels which are wart-like, raised, elliptic in outline and usually transversely divided in the middle (Fig. 1A). Gymnosporia has the flowers mainly functionally unisexual, always with two ovules per locule, capsules shorter than $10 \mathrm{~mm}$, and when lenticels are present on the stems, they are relatively small, pale-coloured circular dots, as in G. nemorosa (Ecklon \& Zeyher 1834/35: 120) Szyszylowicz (1888: 35) (Fig. 1B). Anatomically the leaf blades of Putterlickia are quite different from those of Gymnosporia (Jordaan 1995). A possible anatomical distinction between the pericarp of Putterlickia and Gymnosporia has been reported by Savinov (2006), but this was based on a rather limited survey; sampling of more species is required to confirm the claimed distinction.

In phylogenetic trees derived from molecular studies, Putterlickia is apparently embedded within Gymnosporia (Simmons et al. 2008; McKenna et al. 2011). If this is confirmed by more extensive sampling of taxa and genes, then the recognition of Putterlickia would render Gymnosporia (as currently circumscribed) paraphyletic. To avoid a paraphyletic Gymnosporia (ca. 125 species), proponents of the phylogenetic school of classification have suggested that Putterlickia (five species) be subsumed in Gymnosporia (Simmons et al. 2008; McKenna et al. 2011). However, such a step would have major nomenclatural implications. Valid publication of the genus name Putterlickia (Endlicher 1840) predates that of Gymnosporia (Hooker 1862), a conserved name, though not explicitly so against Putterlickia. Consequently, Putterlickia will have priority as name for the combined genus. On the other hand, it has been convincingly argued that paraphyly is an evolutionary stage of monophyletic (s.1.) taxa that needs to be taken 
into account for purposes of biological classification (e.g., Zander 2013; Brummitt 2014; Stuessy \& Hörandl 2014). Therefore we prefer the evolutionary approach to classification (Mayr \& Bock 2002), thus regarding it essential, when justified, for paraphyletic taxa to be accepted. Putterlickia and Gymnosporia are morphologically and anatomically distinct and their continued recognition at generic level not only better reflects evolutionary divergence, but is also more informative to end-users of plant names (Van Wyk 2007). Moreover, upholding both genera is in the interest of nomenclatural stability.

The first species of Putterlickia to be described was Celastrus pyracanthus Linnaeus (1753: 197), followed by Celastrus verrucosus Sonder (1860: 453). Szyszylowicz (1888) transferred these two species to the genus Putterlickia, established by Endlicher (1840) and named after Alois (Aloys) Putterlick (1810-1845), an Austrian physician and botanist (Stafleu \& Cowan 1983). Davison (1927) and Robson (1966) in revising the Celastraceae for southern Africa, recognised only these two species, namely P. pyracantha (L.) Szyszylowicz (1888: 36) and P. verrucosa (E.Mey. ex Sond.) Szyszylowicz (1888: 36). Although the combination P. pyracantha is still sometimes attributed to (L.) Endl., it was first validly published by Szyszylowicz (Codd 1973). Subsequently, a third species, P. retrospinosa Van Wyk \& Mostert (1987: 267) was added. Jordaan \& Van Wyk (1998) recognised four species, the aforementioned three, plus an additional one when Gymnosporia saxatilis (Burchell 1824: 264) Davison (1927: 303) was transferred to Putterlickia (Jordaan in Jordaan \& Van Wyk 1998: 328).
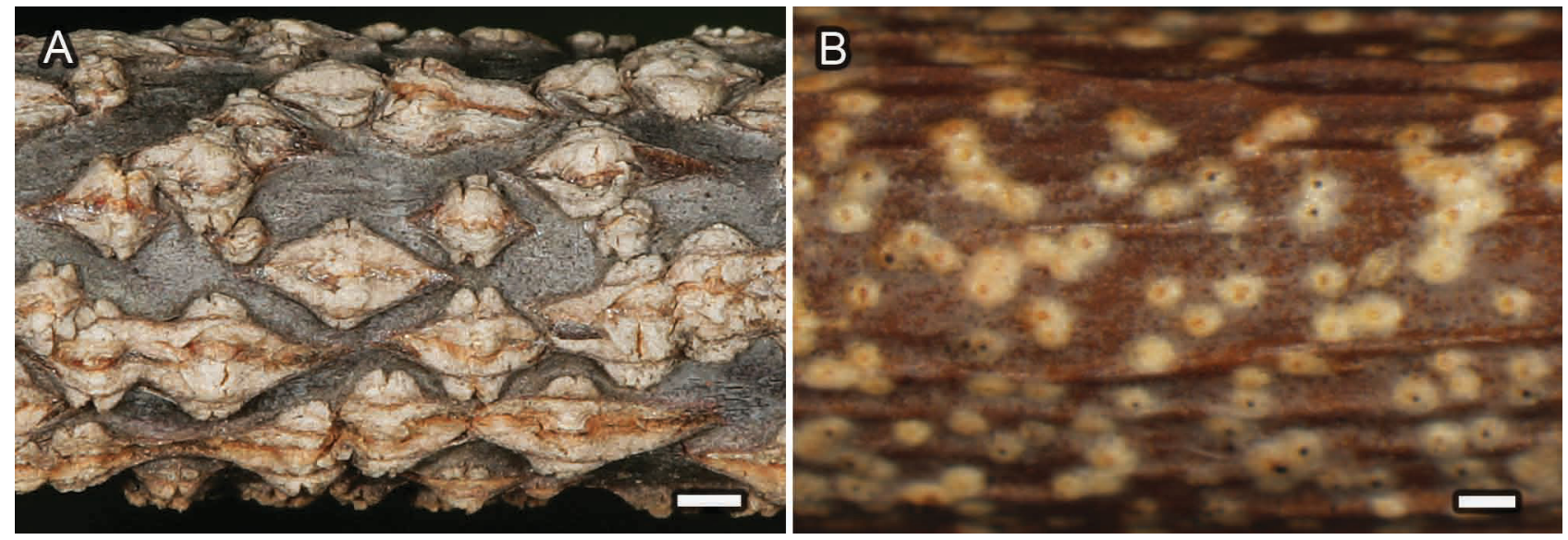

FIGURE 1. Young stem with lenticels. A. Putterlickia neglecta. B. Gymnosporia nemorosa. Scale bar: A = $1.0 \mathrm{~mm}, \mathrm{~B}=0.25 \mathrm{~mm}$. Photographs: A.E. van Wyk.

Putterlickia verrucosa and P. retrospinosa have stems with conspicuous wart-like lenticels (Fig. 1A), but in the case of P. pyracantha and P. saxatilis (Burch.) Jordaan in Jordaan \& Van Wyk (1998: 328) the lenticels are slightly sunken and less prominent. All species of Putterlickia are armed with thorns, as is the case in most members of Gymnosporia. These are reflexed (used for climbing) in P. retrospinosa, but usually straight in all the other species. In herbarium specimens the differences between the Putterlickia species are not always clear, especially in the absence of flowers; the capsules and seed are very similar in size and morphology. At species level Putterlickia has diversified mainly in floral morphology, particularly the size of flowers and pedicel length, whereas Gymnosporia has diversified mainly in fruit, seed and aril characters.

Two of us (MJ \& AEVW) were alerted to the possible existence of a fifth species of Putterlickia when conspicuous differences in floral size were noticed among different plants, all named $P$. verrucosa, in the Pretoria National Botanical Garden (Fig. 2). Subsequent field work by one of us (RGCB) confirmed that the populations hitherto assigned to $P$. verrucosa in north-eastern KwaZulu-Natal have much larger flowers (Fig. 2A) than those further south in the province, as well as extending into the Eastern Cape (Fig. 2B). A comparative study of these two floral morphs have revealed a number of additional morphological differences, all supporting the involvement of two different species. The purpose of the present paper is to describe this northern, large-flowered entity, as a distinct new species that we name $P$. neglecta. In addition to extensive field work covering the full range of Putterlickia, herbarium material of the genus has been studied in NH, PRE and PRU (acronyms according to Thiers 2015).

The photographs labelled Putterlickia verrucosa in Schmidt et al. (2002: 363) and Boon (2010: 315; flowering plant) represent $P$. neglecta. Van Wyk (1994: 247) treated our new species as a northern form of P. pyracantha, presumably because of the larger flowers and entire leaves. The photographs of P. verrucosa in Van Wyk \& Van Wyk (2013: 141) are also of the new species. 

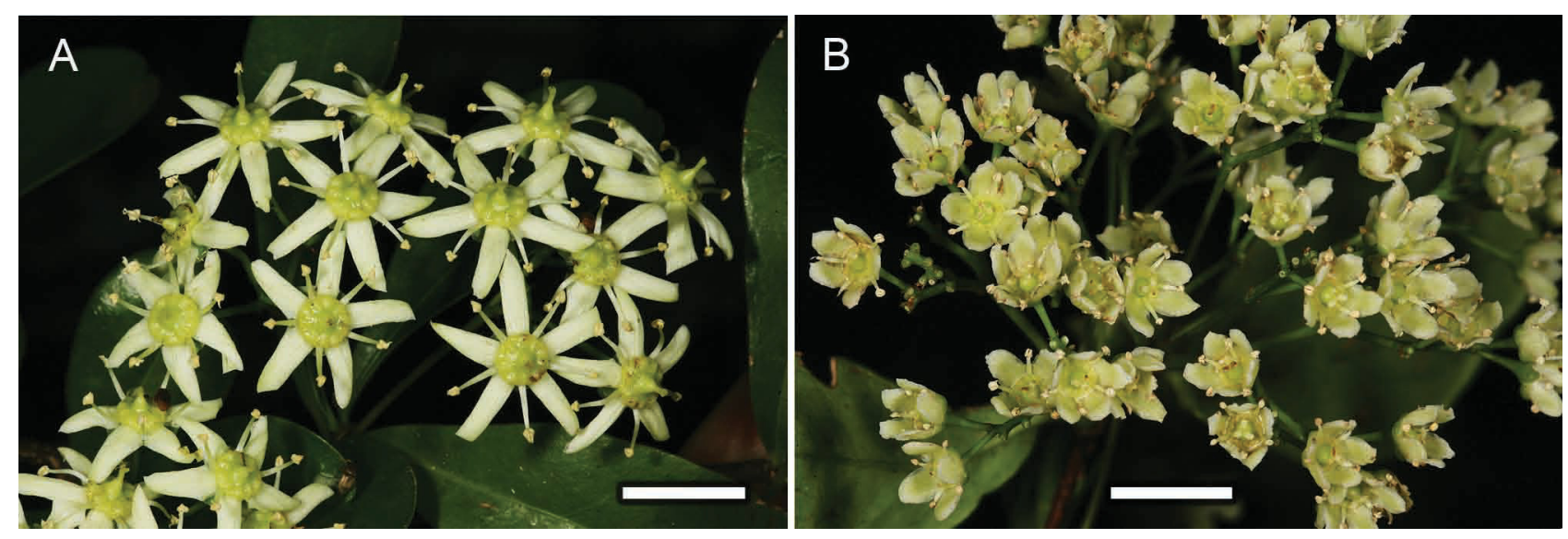

FIGURE 2. Flowers. A. Putterlickia neglecta. B. Putterlickia verrucosa. Scale bar $=4 \mathrm{~mm}$. Photographs: A.E. van Wyk.

\section{Taxonomic treatment}

Putterlickia neglecta Jordaan, R.G.C.Boon \& A.E.van Wyk, sp. nov. (Figs. 1A, 2A \& 3)

Putterlickia neglecta resembles $P$. verrucosa, but is easily distinguished from that species by the leaves being sessile to subsessile with leaf margin usually entire, rarely with scattered remnants of teeth ( $v s$. leaves distinctively petiolate and margin spinulose-denticulate, up to 15 teeth on each side of midrib), pedicels 8-15 mm long ( $v s$. shorter, up to $4 \mathrm{~mm}$ long), petals in freshly opened flowers markedly spreading to slightly recurved ( $v s . \pm$ erect or slightly spreading), up to $6 \mathrm{~mm}$ long ( $v s .1-2 \mathrm{~mm}$ long). It is also similar to $P$. pyracantha, but differs in stems having prominently raised lenticels (vs. obscure, sunken lenticels), leaf apex nearly always emarginate ( $v s$. acute, rounded or truncate to emarginate), leaf margins mostly entire (vs. entire or spinulose-denticulate) and inflorescence axes as well as pedicels greenish (vs. reddish).

Type:-SOUTH AFRICA. KwaZulu-Natal: Sibayi, 2732BC, 2 December 1994, R.A.Lubbe 500 (holotype PRU78273!, isotype K!).

Evergreen straggling shrub or small tree up to $5 \mathrm{~m}$ tall, multi-stemmed, stems to $75 \mathrm{~mm}$ diameter at the base. Branchlets angular when young, becoming terete with age; young stems greyish purple, red-brown becoming grey, usually covered with conspicuous pale, raised, wart-like lenticels, sometimes with stem galls. Thorns axillary, up to 60(-110) mm long, straight, but occasionally slightly reflexed on old stems, usually covered with prominent lenticels, sometimes bearing leaves, flowers and fruit. Brachyblasts sometimes well-developed, up to $6 \mathrm{~mm}$ long. Leaves fasciculate, conspicuously discolourous, mid to dark dull green with a slight bluish tinge above, much paler green and tinged bluish below, bronze-red when young, subsessile; lamina obovate to oblanceolate, (6-)20-70 × 6-30 mm, apex emarginate, base tapering into very short petiole or petiole absent, margin often entire, less frequently with sparse, scattered serrations, revolute, slightly undulate, midrib and reticulate venation prominently raised on both sides when dry. Inflorescence axillary, cymose, usually much longer than leaves; peduncle up to $25 \mathrm{~mm}$ long; pedicels10-14 mm long. Flowers bisexual, 5-merous, white, cream to pale green, $\pm 10 \mathrm{~mm}$ in diam. Sepals green, triangular, $\pm 2 \mathrm{~mm}$ long. Petals widely spreading to somewhat recurved, oblong, $2-4(-6) \times \pm 2.5 \mathrm{~mm}$, apex rounded, margin entire. Disc broad, round, green to pinkish red, margin crenate. Stamens free, slightly shorter than petals. Ovary 3-locular; ovules 6-12 per locule; style $\pm 1.75 \mathrm{~mm}$ long, stigma 3-lobed. Fruit a dry 3-valved capsule, dehiscing loculicidally to base; capsules cream to pink or red, obconic-trigonous, smooth, 15-20(-32) mm long. Seeds oblong, cream, 6-10 mm long, completely enveloped by a well-developed, fleshy orange aril.

Phenology:-Flowers were recorded from October to March. Fruits are encountered on plants all year round.

Etymology:- The specific epithet refers to the fact that this species has for a long time been overlooked as a distinct species.

Distribution and habitat:-Putterlickia neglecta occurs in north-eastern KwaZulu-Natal, from False Bay Park along the coast northwards to Maputo (Mozambique) and inland through the Lowveld in north-eastern and central Swaziland (Loffler \& Loffler 2005: 59) to Mpumalanga (few localities for this province represented as herbarium sheets, notably from Shabin Kop and Numbi in the Kruger National Park) and sight records from the Barberton Mountainlands Nature Reserve (iSpot 2015) and Malelane (Schmidt et al. 2002: 363) (Fig. 4). The species is therefore 
considered a near-endemic to the Maputaland Centre of Endemism (Van Wyk \& Smith 2001). It grows in mixed bushveld (savanna), inland, coastal and dune forests, thicket and riverine vegetation, often on sandy soil.

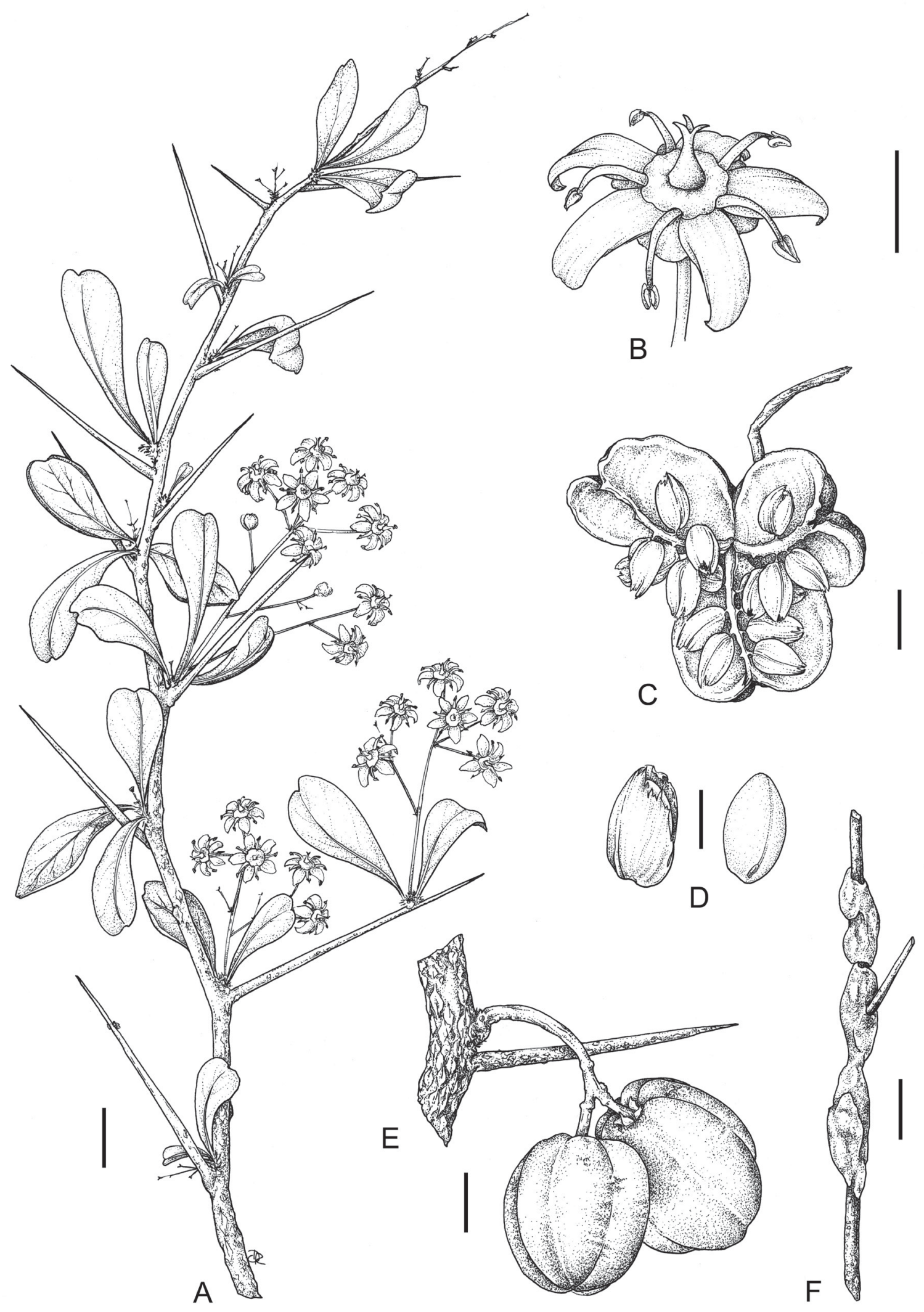

FIGURE 3. Putterlickia neglecta. A. Flowering branchlet; B. Flower; C. Dehisced capsule showing seed; D. Seed completely enveloped by aril left; with aril removed right. E. Capsules; stem with lenticels and thorn. F. Stem with galls. Scale bar = $10 \mathrm{~mm}$. A, B \& F from Jordaan 4317, C from Lubbe 500 and D from Felton \& Thornhill 61. Artist: Daleen Roodt. 


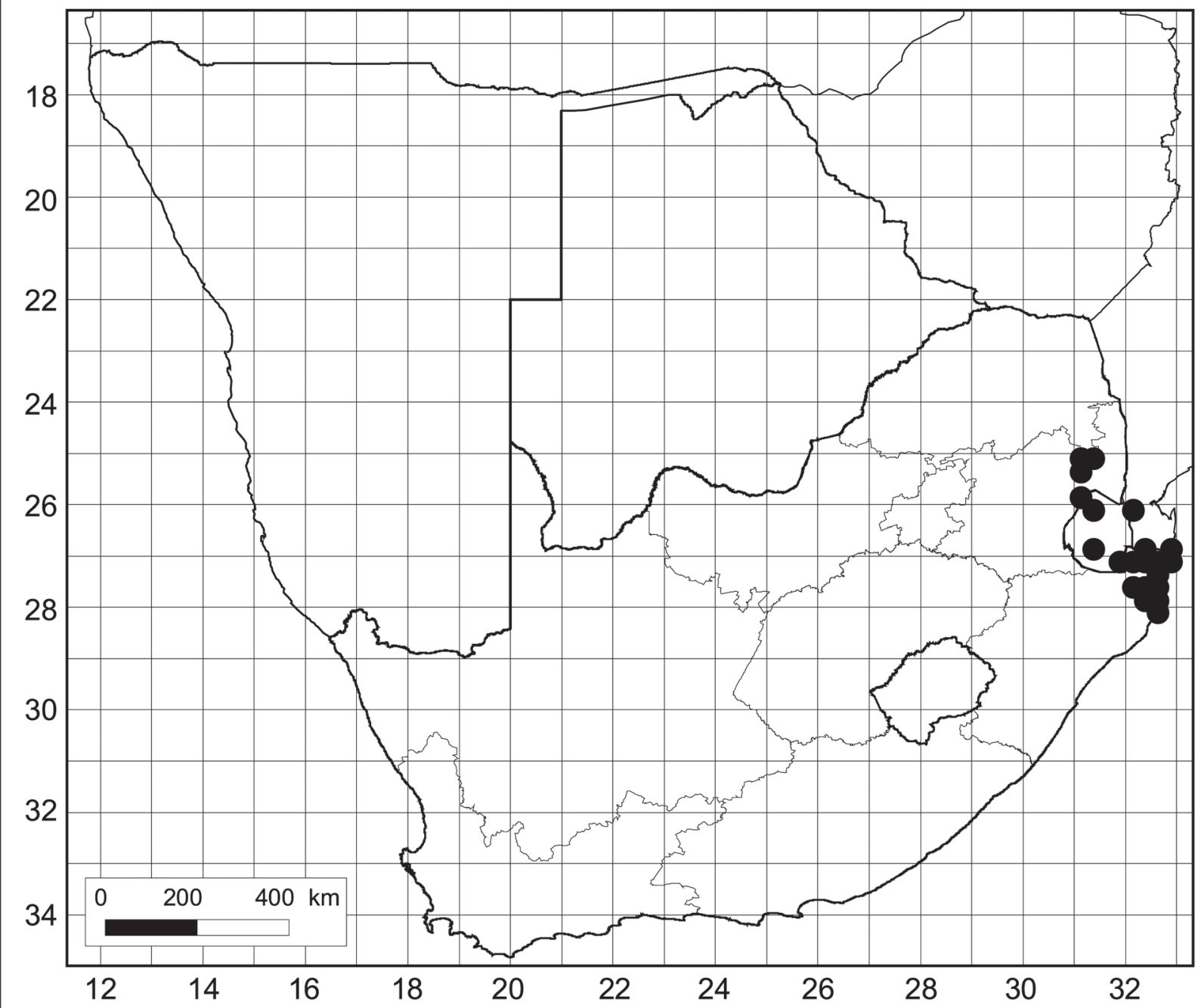

FIGURE 4. Map of southern Africa showing the known distribution of Putterlickia neglecta.

Conservation:- Putterlickia neglecta occurs within the Kruger National Park and a number of protected areas managed by Ezemvelo KZN Wildlife. For most of its range it occurs outside protected areas, but is still fairly common in South Africa and Swaziland where it is considered Least Concern (LC) (IUCN 2012). However, its status in southern Mozambique is unknown as it was last collected there in 1920.

Common names:- The proposed common names for this plant are northern false-spikethorn and noordelike valspendoring (Afrikaans).

Notes:- The more prominent geographical and morphological features to differentiate among the five species of Putterlickia are summarized in Table 1. Although $P$. neglecta is geographically more closely associated with $P$. verrucosa, its relatively large flowers with spreading petal are reminiscent of $P$. pyracantha, a species which occurs much further south. Putterlickia pyracantha occurs on littoral sand dunes in fynbos and scrub along the south-western Cape coast, from the Vredenburg-Saldanha area, to as far north-east at Tsitsa Falls in the Eastern Cape. Putterlickia verrucosa grows from East London to Port St Johns, is replaced by P. retrospinosa in the sandstone region of southern KwaZulu-Natal and Eastern Cape (Van Wyk \& Smith 2001; Pondoland Centre of Endemism), and reappears from Port Shepstone further north along the coast to St Lucia, extending inland up the Umgeni, Tugela and Mhlatuze River Valleys. Putterlickia neglecta replaces P. verrucosa from St Lucia northwards, just entering the southern parts of the Kruger National Park, Mpumalanga (see "Distribution and habitat" above); it is the member of the genus with the most northerly distribution. Putterlickia saxatilis is an easily recognized species with an outlier distribution in the Northern Cape where it is endemic to the Griqualand West Centre of Endemism (Van Wyk \& Smith 2001). 


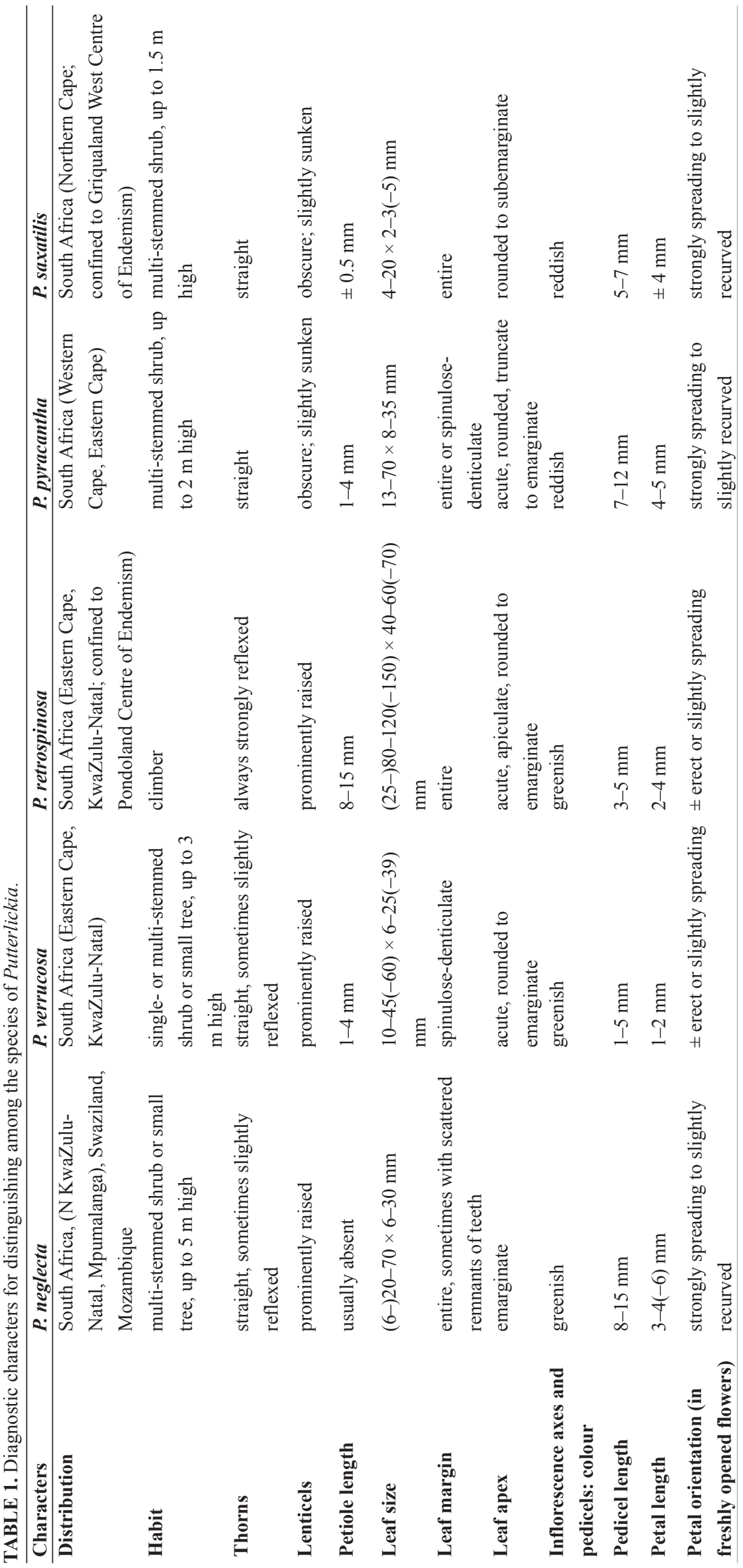


Additional collections (paratypes):-MOZAMBIQUE. Maputo [Lourenço Marques], 18 Jan. 1920, J. Borle 264 (PRE). SWAZILAND. Mlawula Nature Reserve, ravine below Blue Jay cottage, 16 Sep. 1987, R.D. Alward 190 (PRE); E bank of Mkhondo/Assegai River, 30 Aug. 1978, J. Prior 200 (PRE); 20 km S of Sidvokodvo towards Grand Valley, 11 Apr. 1976, E.J. van Jaarsveld 1189 (PRE); $1 \mathrm{~km}$ to the $\mathrm{S}$ of the Komati River, A. de Castro \& M. Brits 362 (PRE). SOUTH AFRICA. Mpumalanga: Kruger National Park, Shabin Kop, near Pretorius Kop, 10 May 1950, L.E. Codd 6063 (PRE), 19 Aug. 1952, H.P. van der Schijff 663 (PRE); Numbi, 15 Jan. 1954, H.P. van der Schijff 3440 (PRE); Lekasi Bantu Town, 20 May 1974, J.P. Nel 384 (PRE). KwaZulu-Natal: Lake Sibayi, 10 Mar. 1977, A. Balsinhas 3190 (PRE), 13 Apr. 1966, E.J. Moll 3174 (PRE), 14 June 1996, Felton \& Thornhill 61 (PRU), 15 Nov. 1995, R.A. Lubbe 734 (PRU); Ingwavuma District, slopes facing Lake Nhlange, 9 Nov. 1958, K.L. Tinley 382 (NH, PRE); Ingwavuma District, 27²1'’S 32²6'E, 4 Jan. 1987, M.C. Ward 1826 (PRE); Gunamanini Pan, Pongola flood plain, 20 June 1972, J. Stephen 821 (PRE); Mavilo Hill, Pongola floodplain, 4 Nov. 1969, E.J. Moll 4267 (NH, PRE); Mkuzi Game Reserve, Mpilo, 19 May 1984, P.S. Goodman 1157 (NH); near Mkuze Game Reserve, slopes of Lebombo range, 20 Nov. 1979, A. Balsinhas 3067 (PRE); \pm 5 km from Makani's Pont on road to Ndumu, 10 Feb. 1979, A.E. van Wyk 2504 (PRE, PRU); road from Bhangazi Lake to beach to Sodwana Bay, 18 May 1985, M. Jordaan 512 (NH, PRE); Sodwana Bay, 26 Mar. 1965, J. Vahrmeijer 648 (PRE), 27 Nov. 1967, R. G. Strey \& E.J. Moll 3953 (NH); between Sodwana Bay and Lake Sibayi, on the road to Driftsand Beach, 25 Apr. 1984, C.N. Buthelezi 458 (NH); Near Manzengwenya Inspection Quarters, 29 Nov. 1969, E.J. Moll 4851 (NH); Manzengwenya Plantation, 10 Dec. 1964, J. Vahrmeijer \& H.R. Tölken 242 (NH); Ubombo, 11 Nov. 1984, G. Nichols \& R. Wise 815 (NH); Dune forest $6 \mathrm{~km}$ N of Cape Vidal, 10 Nov. 1985, K. MacDevette 356 (NH); Mpangazi Lake, 9 Jan. 1964, R. G. Strey 5035 (NH); Sileza Forest, 2705'S 32³6'E, 14 Feb. 1986, M.C. Ward 1361 (NH); Eastern Shores of Lake Sibayi, 23 Feb. 1971, E.J. Moll 5210 (NH), 27²3'S 3242'E, 22 Nov. 1988, M.C. Ward 2402 (NH); Sibaya [Sibayi], 28 Nov. 1967, R. G. Strey \& E.J. Moll 3984 (NH); False Bay Park, January 1982, D. Lawson 156 (NH), 9 July 1961, C.J. Ward 3663 (NH), 28 June 1971, C.J. Ward 7121 (NH, PRE); 29 Nov. 1965, E.J. Moll 2828 (PRE); False Bay Park, 2757'58.85’'S 32²2’45.08”'E, 12 Jan. 2014, R. Boon 59 (NH); False Bay Park, 2758’32.52”S 32²1'49.28”E, 30 Apr. 2014, R. Boon 64 (NH).

\section{Acknowledgements}

We thank Hester Steyn for preparing the distribution map, Daleen Roodt for the line drawings, and two anonymous reviewers for useful comments and suggestions to improve the manuscript.

\section{References}

Archer, R.H. \& Jordaan, M. (2003) Celastraceae. In: Germishuizen, G. \& Meyer, N.L. (Eds.) Plants of southern Africa: an annotated checklist. Strelitzia 14. National Botanical Institute, Pretoria, pp. 354-361.

Boon, R. (2010) Pooley's trees of eastern South Africa. A complete guide. Flora and Fauna Publications Trust, Durban, 626 pp.

Brummitt, R.K. (2014) Taxonomy versus cladonomy in the dicot families. Annals of the Missouri Botanical Garden 100: 89-99. http://dx.doi.org/10.3417/2012089

Burchell, W.J. (1824) Travels in the interior of southern Africa, vol. 2. Longmans, Hurst, Rees, Orme, Brown \& Green, London, 648 pp. http://dx.doi.org/10.5962/bhl.title.100911

Codd, L.E. (1973) Celastraceae. Author citation for Putterlickia pyracantha. Bothalia 11: 115.

Davison, J.D. (1927) Celastraceae R.Br. Bothalia 2: 289-346.

Ecklon, C.F. \& Zeyher, K.L.P. (1834/35) Enumeratio plantarum Africae australis extratropicae: quae collectae, determinatae et expositae, vol. 1. Perth \& Besser, Hamburg, $145 \mathrm{pp}$.

http://dx.doi.org/10.5962/bhl.title.48

Endlicher, S.L. (1840) Ordo CCXXXVI. Celastrineae. Generum plantarum secundum ordines naturales disposita supplementum 5. Beck, Vienna, pp. 1085-1090.

http://dx.doi.org/10.5962/bhl.title.442

Hooker, J.D. (1862) Celastrineae. In: Bentham, G. \& Hooker, J.D. (Eds.) Genera plantarum, vol. 1. Reeve, London, pp. $357-371$. http://dx.doi.org/10.5962/bhl.title.747

iSpot (2015) Available from: http://www.ispot.org.za/node/190087 (accessed 20 May 2015)

IUCN (2012) The IUCN red list categories and criteria, version 3.1., $2^{\text {nd }}$ edition. Gland, Switzerland and Cambridge, UK. Available from: 
http://www.iucnredlist.org/technical-documents/categories-and-criteria/ (accessed 20 May 2015)

Jordaan, M. (1995) A taxonomic revision of the spiny members of subfamily Celastroideae (Celastraceae) in southern Africa. M.Sc. thesis, University of Pretoria, Pretoria, $362 \mathrm{pp}$.

Jordaan, M. \& Van Wyk, A.E. (1998) Systematic studies in subfamily Celastroideae (Celastraceae) in southern Africa: the genus Putterlickia. South African Journal of Botany 64: 322-329.

Linnaeus, C. (1753) Species plantarum 1. Laurentius Salvius, Stockholm, 560 pp. http://dx.doi.org/10.5962/bhl.title.669

Loffler, L. \& Loffler, P. (2005) Celastraceae. Swaziland Tree Atlas, including selected shrubs and climbers. Southern African Botanical Diversity Network Report. No. 35. SABONET, Pretoria, pp. 25-60.

Mayr, E. \& Bock, W.J. (2002) Classifications and other ordering systems. Journal of Zoological Systematics and Evolutionary Research 40: 169-194. http://dx.doi.org/10.1046/j.1439-0469.2002.00211.x

McKenna, M.L., Simmons, M.P., Bacon, C.D. \& Lombardi, J.A. (2011) Delimitation of the segregate genera of Maytenus s. 1. (Celastraceae) based on morphological and molecular characters. Systematic Botany 36: 922-932.

http://dx.doi.org/10.1600/036364411X604930

Robson, N.K.B. (1966) Celastraceae. In: Exell, A.W., Fernandes, A. \& Wild, H. (Eds.) Flora Zambesiaca 2, 2. Crown Agents for Overseas Governments and Administration, London, pp. 355-418.

Savinov, I.A. (2006) Some morphological basics for a revision of the tribe Celastreae Loes. (Celastraceae R.Br.). Wulfenia 13: $207-215$.

Schmidt, E., Lötter, M. \& McCleland, W. (2002) Trees and shrubs of Mpumalanga and Kruger National Park. Jacana, Johannesburg, 702 pp.

Simmons, M. P., Cappa, J.J., Archer, R.H., Ford, A.J., Eichstedt, D. \& Clevinger, C.C. (2008) Phylogeny of the Celastreae (Celastraceae) and the relationships of Catha edulis (qat) inferred from morphological characters and nuclear and plastid genes. Molecular Phylogenetics and Evolution 48: 745-757.

http://dx.doi.org/10.1016/j.ympev.2008.04.039

Sonder, O.W. (1860) Celastrineae. In: Harvey, W.H. \& Sonder, O.W. (Eds.) Flora Capensis, vol. 1. Hodges \& Smith, Dublin, pp. 452460 .

http://dx.doi.org/10.5962/bhl.title.821

Stafleu, F.A. \& Cowan, R.S. (1976-1988) Taxonomic literature, vol. 1-7, edn 2. Bohn, Scheltema \& Holkema, Utrecht. http://dx.doi.org/10.5962/bhl.title.48631

Stuessy, T.F. \& Hörandl, E. (2014) Evolutionary systematics and paraphyly: introduction. Annals of the Missouri Botanical Garden 100: $2-5$.

http://dx.doi.org/10.3417/2012083

Szyszylowicz, I.R. Von (1888) Polypetalae disciflorae Rehmannianae. Universitatis Jagellonicae, Krakau, 75 pp.

Thiers, B. (2015) Index Herbariorum: a global directory of public herbaria and associated staff. New York Botanical Garden's Virtual Herbarium. Available from: http://sweetgum.nybg.org/ih/ (accessed 24 April 2015)

Van Wyk, A.E. (2007) The end justifies the means. Taxon 56: 645-648.

http://dx.doi.org/10.2307/25065849

Van Wyk, A.E. \& Mostert, S.C. (1987) A new species of Putterlickia (Celastraceae) from southern Natal and Pondoland. South African Journal of Botany 53: 267-270.

Van Wyk, A.E. \& Smith, G.F. (2001) Regions of floristic endemism in southern Africa: a review with emphasis on succulents. Umdaus Press, Hatfield, Pretoria, 199 pp.

Van Wyk, B. \& Van Wyk, P. (2013) Field guide to trees of southern Africa, $2^{\text {nd }}$ edn. Struik Nature, Cape Town, 732 pp.

Van Wyk, P. (1994) Field guide to the trees of the Kruger National Park. Struik Publishers, Cape Town, 272 pp.

Wight, R. \& Arnott, G.A.W. (1834) Prodromus florae peninsulae Indiae orientalis, vol. 1. Allen \& Co., London, 480 pp. http://dx.doi.org/10.5962/bhl.title.252

Zander, R.H. (2013) A framework for post-phylogenetic systematics. Zetetic Publications, St. Louis, 209 pp. 